\title{
11
}

\section{Foreign direct investment in China Trends and characteristics after WTO accession}

\section{Chunlai Chen}

Foreign direct investment (FDI) in China has been one of the most significant features of the country's economic reform and opening up to the outside world. The gradual liberalisation of restrictions on FDI since 1979 and the government's commitment to further opening up have greatly improved the investment environment. Foreign firms have been attracted by the huge domestic market and pool of relatively well-educated, low-cost labour, which has made China one of the most attractive destinations for FDI in the world.

China became a member of the World Trade Organization (WTO) in December 2001, after 15 years of negotiations in which China agreed to reduce tariff and non-tariff barriers to trade in agriculture and manufactured goods, to liberalise and open trade in services to foreign participation, remove restrictions on FDI-particularly in services-and improve protection of intellectual property rights. In terms of FDI, China has made substantial commitments in investment liberalisation, especially in the services sector, and has agreed to comprehensively implement the Trade-Related Investment Measures (TRIMs) agreement. Undoubtedly, the reduction in foreign investment barriers and the liberalisation of the FDI regime will provide great opportunities for foreign investors to operate in China.

There have been many studies on the impact of China's entry into the WTO on FDI inflows into the country (for example, McKibbin and Wilcoxen 1998; Hu 1999; Walmsley and Hertel 2000; UNCTAD 2000; Chen 2002). The most common findings are that China's WTO accession will have a positive impact on its gross domestic product (GDP) growth-mainly through efficiency gains resulting 
from trade and investment liberalisation - and it will accelerate FDI inflows into China and increase the share of foreign ownership in China's assets.

What, however, has really happened with FDI inflows since China's WTO accession? This chapter intends to provide a brief overview of the trends and characteristics of FDI inflows into China since its WTO accession by analysing aspects of the general trend of FDI inflows, the composition of FDI sources, the sectoral and regional distribution of FDI inflows and the structure of FDI in China's manufacturing.

\section{The general trend of FDI inflows into China}

FDI inflows into China presented three distinct phases (see Figure 11.1): the experimental phase from 1979 to 1991, the boom phase from 1992 to 2001, and the post-WTO phase from 2002 to 2006.

During the experimental phase, FDI inflows were low, but they grew steadily. The period was characterised by small investment projects, high investment costs, restrictive price controls, poor infrastructure and lack of legal frameworks.

In the second phase, FDI inflows initially increased very rapidly, however, they slowed after 1997 and declined in 1999 and 2000, followed by a moderate recovery in 2001. The slow-down from 1997 to 2000 could be explained by several factors. First, there has been a slow-down from the surge in transfers of labour-intensive activities from neighbouring Asian economies. In addition, the East Asian financial crisis weakened substantially the outward investment abilities of East and Southeast Asian economies. As a result, FDI flows into China from East and Southeast Asia declined substantially since 1997. Second, market rates of return to investment in China have not been as high as foreign investors expected. Informal relationships and corruption still hinder many business transactions by foreigners. In addition, inefficient state-owned enterprises continue to dominate many key sectors of the economy, especially the services sector. Third, there still are restrictions on FDI, such as on ownership shares, modes of FDI entry, business operations and regional and sectoral restrictions.

Therefore, China's accession to the WTO came at a critical time, when the country was facing difficulties sustaining a high level of FDI inflows. Could China's WTO accession revive the trend of increasing high levels of FDI inflows?

After entry into the WTO-with the implementation of its commitments and broader and deeper liberalisation in trade and investment-China's economy has been growing rapidly. The average annual growth rate of China's GDP was 
Figure 11.1 FDI inflows into China, 1980-2006 (US\$ billion at current prices)

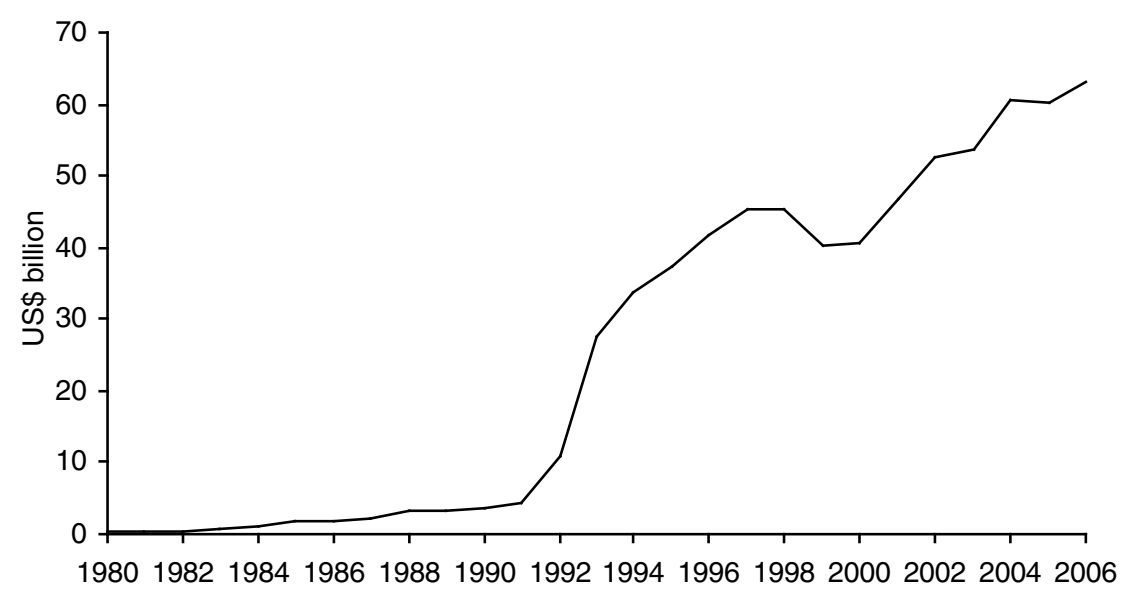

Source: National Bureau of Statistics, various issues (a). China Statistical Yearbook, China Statistical Press, Beijing.

10 per cent during 2002-06..$^{1}$ China's foreign trade has been expanding even more rapidly than its overall economic growth. The total value of China's foreign trade increased from US $\$ 509.65$ billion in 2001 to US $\$ 1,760.4$ billion in 2006, with an annual growth rate of 28.2 per cent. Undoubtedly, China's economy has benefitted from entry into the WTO, especially from a more open and liberalised international trade and FDI regime.

After China's accession to the WTO, FDI inflows presented an increasing trend. FDI inflows increased from US $\$ 46.9$ billion in 2001 to US $\$ 63$ billion in $2006,{ }^{2}$ with an annual growth rate of 6.1 per cent (Figure 11.1). This has demonstrated that with trade and investment liberalisation and reduction in foreign investment barriers, China's WTO accession has accelerated FDI inflows.

There has, however, long been an issue of 'round-tripping' of investment in China. Round-tripping is driven by differences in the treatment of foreign and domestic investors, which can motivate investors to channel funds out of, and subsequently into, an economy in the form of FDI. Because the funds originate in the host economy itself, round-tripping inflates FDI inflows. In China, because of the preferential treatment offered to foreign investors (mainly through tax 
incentives), a significant share of FDI inflows are round-tripped, mainly via Hong Kong (UNCTAD 2007) and, more recently and increasingly, via tax havens such as the Virgin, Cayman and Samoan islands (He 2006). Official estimates from the Chinese government are not available, but one estimate, made by Harrold and Lall (1993), suggested that round-tripping inward FDI accounted for 25 per cent of China's FDI inflows in 1992. Some experts estimate that round-tripping FDI currently accounts for 33 per cent of China's total FDI inflows (He 2006).

On 16 March 2007, Chinese lawmakers passed the much talked about corporate income tax law, unifying tax rates for foreign and domestic enterprises. The new tax rate for domestic and foreign enterprises will be 25 per cent. The law is due to take effect on 1 January 2008 (Xinhua News Agency 2007). The new law has unified the two existing tax codes-one for domestic enterprises, the other for foreign-invested enterprises-and represents a fundamental change in China's tax policy. Many of the tax incentives and tax holidays that existed in the old code for foreign investors have been changed or eliminated.

Undoubtedly, the new law and the unification of the tax rate will substantially reduce the incentive for round-tripping. What, however, are the impacts of the new tax law on domestic and foreign-invested companies and on FDI inflows into China?

Although the current nominal income tax rate is set at 33 per cent, the real average income tax burden on China's domestic companies is 25 per cent (Xinhua News Agency 2007), so on average the new tax law will not reduce the real tax burden on domestic companies.

The current real income tax burden on foreign-invested companies is $15 \mathrm{per}$ cent (Xinhua News Agency 2007). On average, the new law will increase the tax burden on foreign-invested companies by 10 percentage points. It seems that the new law will have a negative impact on foreign-invested companiesespecially in the short term on small-scale, labour-intensive, quick profit-earning enterprises from developing economies.

I would argue, however, that China's proposed unified corporate income tax rate of 25 per cent for domestic and foreign-invested companies will have little effect on foreign investment in China, especially from large multinational enterprises.

First, the average corporate income tax rate for the 159 countries and regions that levy corporate income tax is 28.6 per cent, and the average corporate income tax rate for China's 18 neighbouring countries and regions is 26.7 per cent (Xinwen Shishi 2007). China's proposed unified tax rate of 25 per cent is below the global average, so it is quite competitive for attracting foreign and domestic investment, therefore, there is little reason to believe that the new law will have a significant effect on foreign investment. 
Second, in the past few decades, time-series econometric analyses and numerous surveys of international investors have shown that tax incentives are not the most influential factor for multinationals when selecting investment locations (Morisset 2003). Foreign investors are, of course, interested in tax rates, but they are more interested in factors such as a broad investment climate and domestic market, the cost and availability of labour, basic infrastructure, economic and political stability, and the like.

Third, China's overall investment environment is quite competitive, with relatively efficient public services, good infrastructure, a large and fast-growing domestic market, abundant and well-educated human resources, low labour costs and macroeconomic and political stability-making China one of the most attractive locations for FDI. According to the 2005 Foreign Direct Investment Confidence Index (A.T. Kearney Inc. 2007), in 2005 China was the world's most attractive FDI location in the world. China has maintained its lead in the index for the fourth consecutive year. Once again, China is the top FDI location for first-time investors, with more than half (55 per cent) of investors expected to make first-time investments there in the next three years. One in five FDI dollars for first-time investments will be committed to the Chinese market. China has successfully overcome the perceived risk associated with first-time market entry, which is typically the biggest barrier to generating new FDI.

Fourth, the new tax law still has preferential stipulations: China will continue to offer tax incentives to investment in projects relating to environmental protection, agricultural development, water conservation, energy saving, production safety, high-technology development and public welfare. Hightechnology enterprises can still enjoy a 15 per cent income tax rate, and small and medium-sized enterprises with slim profits are required to pay income tax at only 20 per cent. Certain tax breaks will also be granted to enterprises in special economic zones and in the less-developed western areas of the country (Xinhua News Agency 2007).

Finally, the new tax law also provides five-year transitional periods to offset the impact on foreign companies. The income tax rate will be increased gradually to 25 per cent during this period, and existing foreign enterprises can still enjoy tax breaks within a regulated time limit (Xinhua News Agency 2007).

Therefore, the new law will bring China's tax laws more in line with international standards. It is the fulfilment of a commitment to the WTO for equal treatment for domestic and overseas investors. The change in the law not only proves that the Chinese government is determined to continue its reform and opening up policies - and to work hard to improve the investment climate-it will help to create a sound investment environment and promote China's industrial restructuring and upgrading. 


\section{The composition of FDI sources}

By the end of 2001, FDI in China was dominated overwhelmingly by developing economies, which accounted for 73.8 per cent of the total accumulated FDI inflows, while industrialised economies accounted for only 26.2 per cent. In terms of individual investors, FDI was dominated by four investors: Hong Kong, the United States, Japan and Taiwan, accounting for 48 per cent, 8.7 per cent, 8.2 per cent and 7.3 per cent of the total accumulated FDI inflows respectively.

After China's accession into the WTO, developing and industrialised economies increased investments in China. FDI inflows from developing economies increased from US $\$ 32.2$ billion in 2001 to US $\$ 39.8$ billion in 2005, with an annual growth rate of 5.4 per cent. FDI inflows from industrialised economies also increased but at a much slower pace, rising from US\$13.6 billion in 2001 to US $\$ 14.4$ billion in 2005 , with an annual growth rate of 1.5 per cent (Figure 11.2).

Among the major investors from developing economies, Hong Kong is still the largest; however, its FDI inflows into China stagnated at about US\$16-17 billion from 2001 to 2005 (Table 11.1). As a result, its share in total FDI inflows into China declined from 48.1 per cent at the end of 2001 to 32 per cent in the period 2002-05. FDI inflows from Taiwan and Singapore increased in 2002 and then declined continuously. Consequently, their shares also declined in the period 2002-05. In contrast, FDI inflows from South Korea increased dramatically from US $\$ 2.1$ billion in 2001 to US $\$ 4.6$ billion in 2005. As a result, its share increased from 3.1 per cent at the end of 2001 to 8.2 per cent in the period 2002-05.

The most notable feature is the large increase in FDI inflows from three tax-haven economies - the Virgin, Cayman and Samoan islands. FDI inflows from the Virgin Islands increased dramatically from US $\$ 4.9$ billion in 2001 to US $\$ 8.1$ billion in 2005 , an increase of 64.8 per cent. As a result, its share in total FDI inflows increased from 4.4 per cent at the end of 2001 to 12.1 per cent in the period 2002-05, making it the second largest investor in China during this period. Investments from the Cayman and Samoan islands also increased, as did their shares in total FDI inflows into China in the period 2002-05.

The large increase in FDI inflows into China from the three tax-haven island economies might involve 'round-tripping', as discussed above, in which domestic Chinese investors invest in the tax-haven economies (often through a shell company) and then reinvest in China to take advantage of the preferential treatment offered to foreign investors.

Another explanation for the rise in FDI into China from the Virgin, Cayman and Samoan islands is the 'transit' investment in China from other economiesnotably Hong Kong and Taiwan-via the island economies in order to lower (or 
Figure 11.2 FDI inflows into China, by source, 1983-2005 (US\$ billion at constant 2000 prices)

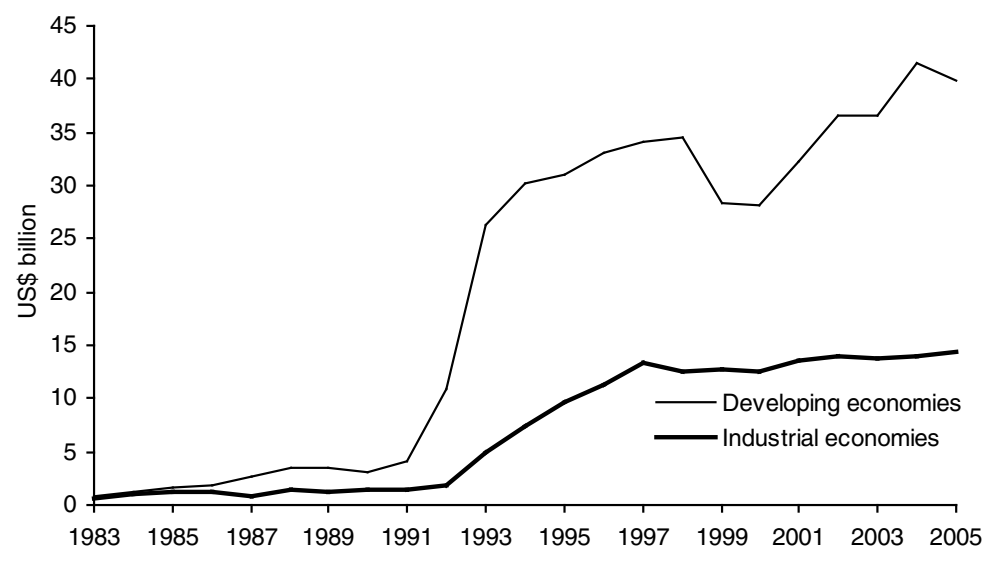

Source: National Bureau of Statistics, various issues (a). China Statistical Yearbook, China Statistical Press, Beijing.

eliminate) their fiscal commitments. For example, the number of companies in Hong Kong that are incorporated in Bermuda and the Cayman Islands jumped 5.2 times from 178 in 1990 to 924 in 2000 (Wu et al. 2002). As for Taiwanese companies, partly to take advantage of the tax regime, but also to bypass the Taiwanese government's restrictions on investment in the mainland, the Virgin Islands and the Cayman Islands rank second and third respectively after China as the biggest recipients of Taiwan's outward investment (Breslin 2003). This suggests that FDI in China from Hong Kong and Taiwan is more significant than the official data reveal. The data also reflect use of tax havens by investors from industrialised economies.

In terms of the major investors from industrialised economies, FDI inflows from the United States increased from US $\$ 4.3$ billion in 2001 to US $\$ 5.2$ billion in 2002, then declined continuously to US $\$ 2.7$ billion in 2005. As a result, its share in total FDI inflows into China declined from 8.7 per cent (making it the second largest investor) at the end of 2001 to 7.4 per cent (ranking it in fourth place) in the period 2002-05. Investment from the United Kingdom dropped from US $\$ 1$ billion in 2001 to about US $\$ 0.8$ billion during 2002 and 2005, while investment from France increased marginally during the period 2001-05. In 


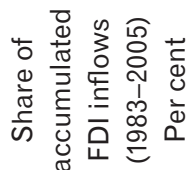

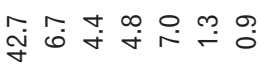

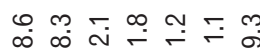
싯 $\stackrel{m}{\dot{i}} \dot{0}$

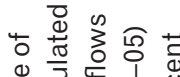

凹

क

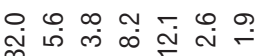

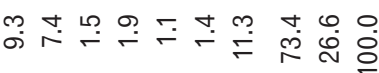

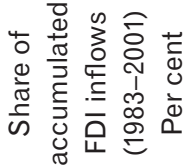

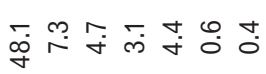

๙

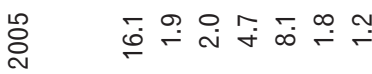

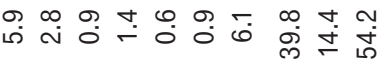

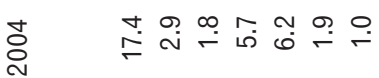

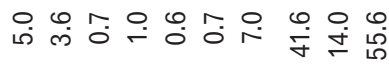

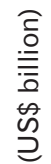

농

岂

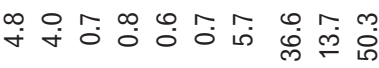

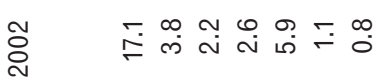

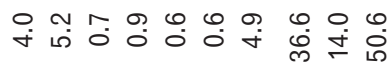

ำ

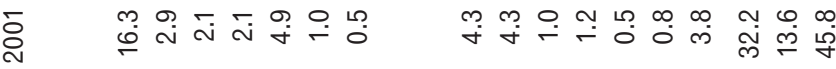

突

문

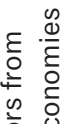

$\stackrel{\oplus}{\frac{\mathscr{e}}{\varepsilon}}$

s)

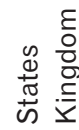

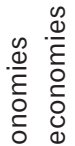

i⿱ 口)

बु.

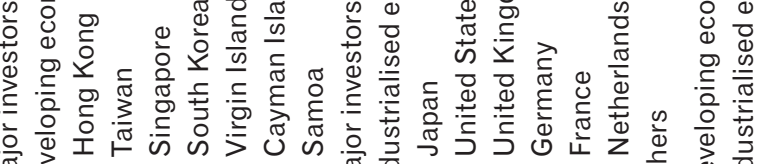

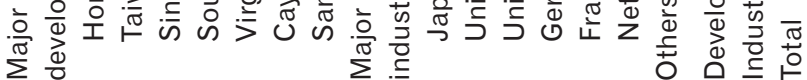

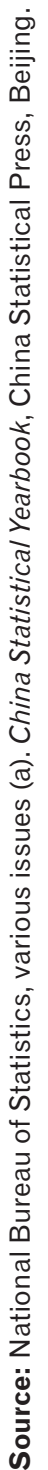


contrast, FDI inflows from Japan increased from US $\$ 4.25$ billion in 2001 to US $\$ 5.9$ billion in 2005 , maintaining its position as the third largest investor in China in the period 2002-05. Investments from Germany and the Netherlands also increased in 2005.

FDI inflows from other countries presented an increasing trend, rising from US $\$ 3.8$ billion in 2001 to US $\$ 6.1$ billion in 2005. As a result, their combined share in total FDI inflows into China increased from 8.2 per cent at the end of 2001 to 11.25 per cent in the period 2002-05. The increasing share of FDI inflows from other countries is an indication of the diversification of FDI sources.

In general, since China's WTO accession, developing and industrialised economies have increased their investments in the China because of the overall improvement of the investment environment and the reduction of trade and investment barriers. The growth rate of FDI inflows from developing economies is, however, much faster than that of industrialised economies. As a result, developing economies still dominate FDI inflows into China, and the composition of FDI sources in terms of developing and industrialised economies has barely changed.

The domination of developing economies in FDI in China could be attributed to their economic development level and the nature and characteristics of their firms. Because developing economies have moderate technological and innovative capabilities and are at the mid-level of economic development, the ownership advantages possessed by their firms are concentrated in the forms of labour-intensive production technology, standardised product manufacturing and well-established export market networks. Obviously, China-having relatively abundant labour resources and a comparative advantage in labourintensive activities-is an attractive location for developing-economy investors to explore overseas investment opportunities, particularly for export-oriented FDI. Since its accession to the WTO, China has, on the one hand, reduced trade and investment barriers and improved the investment environment, while, on the other, its export markets have been greatly enlarged as WTO member countries-particularly industrialised economies-have opened domestic markets for China's exports. Therefore, there are great incentives for developing-country investors to increase FDI in China in general and to increase export-oriented FDI in particular. It is expected that China will remain an important host country for investments from developing economies well into the future.

In general, enterprises from industralised economies with high technological and innovative capabilities and high overall economic development levels will possess greater ownership advantages in the form of high technology, 
product differentiation, managerial and entrepreneurial skills and intangible knowledge-based assets than those from developing economies. Because of these enterprise-specific ownership advantages, FDI from industrialised economies is more market-oriented than that from developing economies. The general implication is that host countries with larger markets, faster economic growth and a higher degree of economic development will attract more market-oriented FDI. China's huge domestic market, fast economic growth and increasing per capita income are very attractive to industrialised-country investors, particularly to market-oriented FDI. Therefore, China's accession to the WTO has provided great opportunities for industrialised-country investors to explore China's huge domestic markets. It is expected that with fulfilment of China's commitments to the WTO in trade and investment liberalisation, China will become an increasingly important host country for FDI from industrialised economies, which will not only increase the total FDI inflows from industrialised economies, it will increase their quality.

\section{Regional distribution of FDI inflows}

Since China started to attract FDI, the regional distribution of FDI inflows has been very uneven. FDI inflows into China are concentrated overwhelmingly in the east of the country. Although there have been some small fluctuations, the gap between the eastern and the central and western regions has been increasing, especially since the early 1990s. By the end of 2001, the eastern region attracted 87.8 per cent of the total FDI inflows into China, while the central and western regions received only 9 per cent and 3.3 per cent of the total respectively.

Trade and investment liberalisation are expected to bring more benefits to the eastern region than to the rest of the country, especially the western region. Therefore, economic growth in the east will be higher and faster than in the west. Consequently, it is expected that more FDI will flow into the eastern region and the uneven regional distribution of FDI inflows into China-especially between the eastern and the western regions-might be reinforced in the short term.

After China's WTO entry, FDI inflows continued to concentrate in the eastern region-increasing rapidly from US $\$ 39.8$ billion in 2001 to US $\$ 48$ billion in 2004 , with an annual growth rate of 6.5 per cent (Figure 11.3 and Table 11.2). From 2002 to 2004 , the eastern region attracted US $\$ 135.2$ billion in FDI inflows, accounting for 86.8 per cent of the total during that period. Among the provinces in the eastern region, Jiangsu's performance was the most outstanding. During the period 2002-04, Jiangsu attracted US $\$ 27.9$ billion in FDI inflows, accounting for 17.9 per cent of the total. As a result, Jiangsu surpassed Guangdong in 
attracting FDI inflows and became the largest FDI recipient in China during the period. Although its share has been declining, Guangdong is still one of the most attractive locations for foreign investment. It attracted US $\$ 27.4$ billion in FDI inflows, accounting for 17.6 per cent of the total during the period 2002-04. Liaoning, Shanghai and Zhejiang also witnessed a large increase in FDI inflows and their shares in the total have increased. In contrast, FDI inflows into Fujian, Guangxi and Hainan have declined.

The central region has witnessed a large increase in FDI inflows since 2001: from US $\$ 4.1$ billion in 2001 to US $\$ 6.4$ billion in 2004, with an annual growth rate of 16.2 per cent. As a result, its share in total FDI inflows into China increased from 9 per cent at the end of 2001 to 10.9 per cent in the period 2002-04. In the central region, the increasingly attractive provinces for FDI are Jiangxi, Hubei and Hunan. These three provinces contributed to the majority of the increase in FDI inflows into the central region.

The western region has experienced a declining trend in FDI inflows since 2001: from US $\$ 1.4$ billion in 2001 to US $\$ 1$ billion in 2004, with an annual declining rate of 10.3 per cent. Provinces with a large decline in FDI inflows were Sichuan, Shaanxi and Gansu.

Figure 11.3 FDI inflows into China by region, 1983-2004 (US\$ billion at constant 2000 prices)

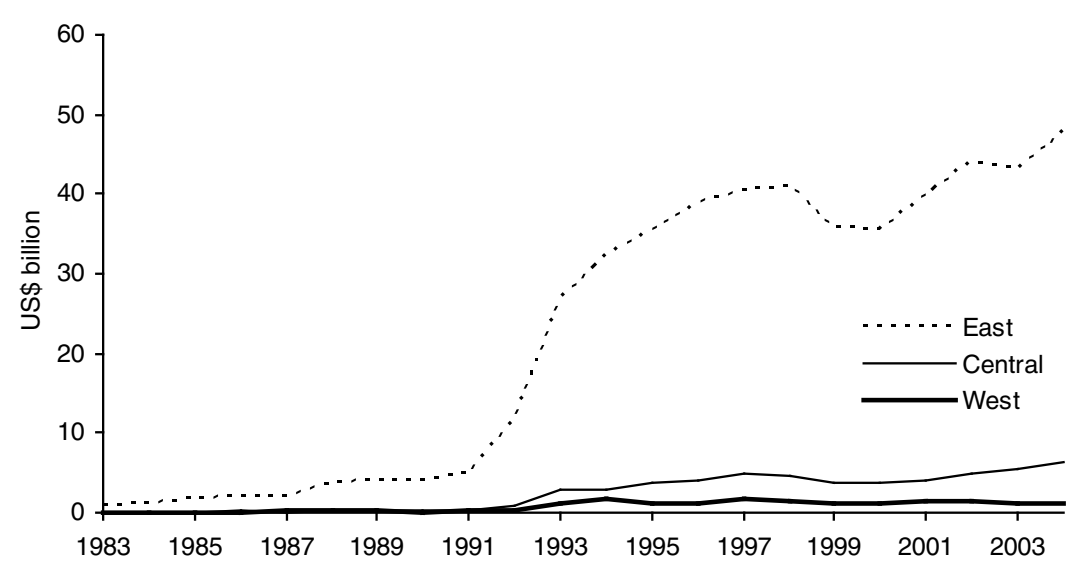

Sources: National Bureau of Statistics, various issues (a). China Statistical Yearbook, China Statistical Press, Beijing. 


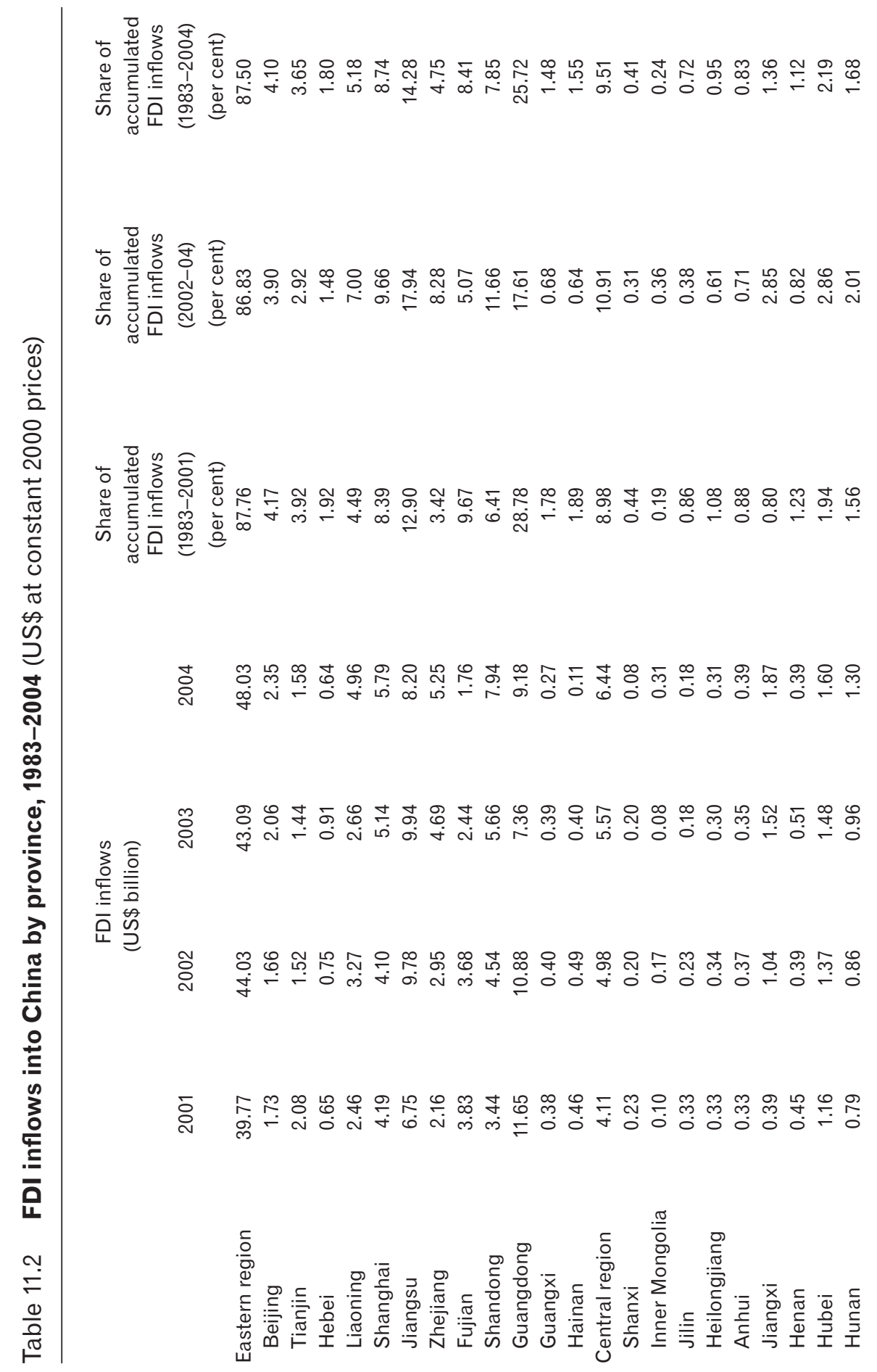




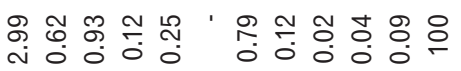

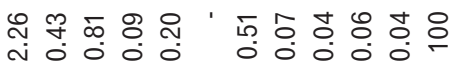

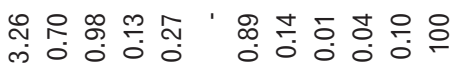

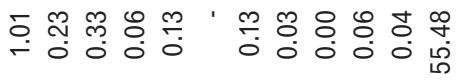

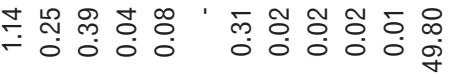

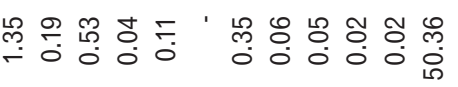

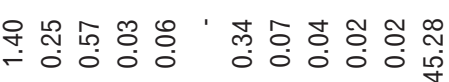

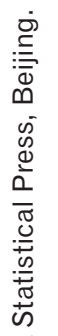


It was hoped that China's accession to the WTO would help to improve the uneven regional distribution of FDI inflows, however, evidence has shown that since accession, the pattern of regional distribution has been essentially maintained. The eastern region is still the most attractive for FDI, the central region is increasing its attractiveness and the western region still has a long way to go to improve its overall investment environment.

The attractiveness of the eastern region to FDI is its relatively more open and developed economy, closer connections with the outside world, better infrastructure, higher levels of scientific research and technical innovation and the higher quality of its labour forces. Therefore, it is expected that with further liberalisation in trade and investment, the region will attract more FDI inflows.

The poor performance of the western region is attributed mainly to its poor overall investment environment. To boost economic growth and thereby reduce the gap between the eastern and the central and western regions, the Chinese government launched the West Development Strategy in $1998 .^{3}$ The strategy emphasises infrastructure development, environmental protection, industrial structural readjustment, development of sciences and education and economic reform and openness. To improve the investment environment and accelerate economic growth in the western region, China has invested heavily in infrastructure development. According to the western development strategy, major infrastructure projects include, for example: investing 120 billion yuan in highway and road construction between 2000 and 2020; investing 100 billion yuan in large and medium-sized railway projects between 2000 and 2005; creating a hydroelectricity generation base in the western region and constructing a national electricity supply network to transport electricity from the west to the east, between 2000 and 2015; investing 300 billion yuan in gas pipeline construction to transport natural gas from the west to the east, between 2000 and 2007; and constructing more airports in the western region (Office of the West Development Leading Group of the State Council 2000).

Undoubtedly, the western development strategy and the further opening up of the central and western regions have provided great opportunities for foreign investors. The comparative advantages of the central and western regions are rich natural resources, low labour costs and growing markets. In addition, there are many state-owned enterprises in these regions with huge amounts of idle capital stock. China is stipulating relevant laws and regulations on crossborder mergers and acquisitions and foreign investors are being encouraged to participate in state-owned enterprise reform and transformation through mergers and acquisitions. Such measures are aimed at increasing the flow of 
foreign capital into the central and western regions in the medium and long term. However, this had not been manifested in direct foreign investment flows into the west up to 2004.

\section{Sectoral distribution of FDI inflows}

By the end of 2001, the sectoral distribution of FDI in China was characterised by its concentration in the manufacturing sector, which attracted 61 per cent of the total FDI inflows into China during the period 1997-2001; the services sector attracted 36 per cent, while the primary sector attracted only 3 per cent. ${ }^{4}$

After WTO accession FDI inflows continued to concentrate in the manufacturing sector, increasing from US $\$ 30.2$ billion in 2001 to US $\$ 38.2$ billion in 2005, with an annual growth of 6 per cent (Table 11.3). As a result, the share of FDI inflows into the manufacturing sector increased from 66 per cent in 2001 to 70 per cent in 2005.

Studies of the impacts of China's WTO accession predict that, after accession, China's labour-intensive manufacturing industries-especially textiles and clothing - will grow rapidly, led by the expansion of exports as a result of the reduction of import tariffs and the elimination of import quotas from industrialised economies on China's labour-intensive manufactured goods. To realise this potential, however, China needs to introduce foreign capital, technology and advanced equipment to help upgrade its relatively backward labour-intensive industries in order to compete in global markets. Therefore, WTO accession provides great opportunities for foreign investors to invest in China's labour-intensive and export-oriented manufacturing industries. It is expected that more FDI will flow into these industries.

China's accession also provides great opportunities for foreign companies to invest in China's capital-intensive and technology-intensive manufacturing industries. Foreign companies in these industries have advantages over China's domestic enterprises. With further implementation of its WTO commitments, China will further relax controls on foreign ownership, allow direct transactions of cross-border mergers and acquisitions by foreign companies of its enterprises-especially state-owned enterprises-and improve the protection of intellectual property rights. As a result, it is expected that increasing amounts of FDI-especially from large industrialised-country multinationals-will flow into China's capital-intensive and technology-intensive manufacturing industries.

FDI inflows into the primary sector continued to decline after 2001: their share declined from 4 per cent in 2001 to only 2 per cent in 2005. This is not surprising given the declining share of the agricultural sector in China's national economy 


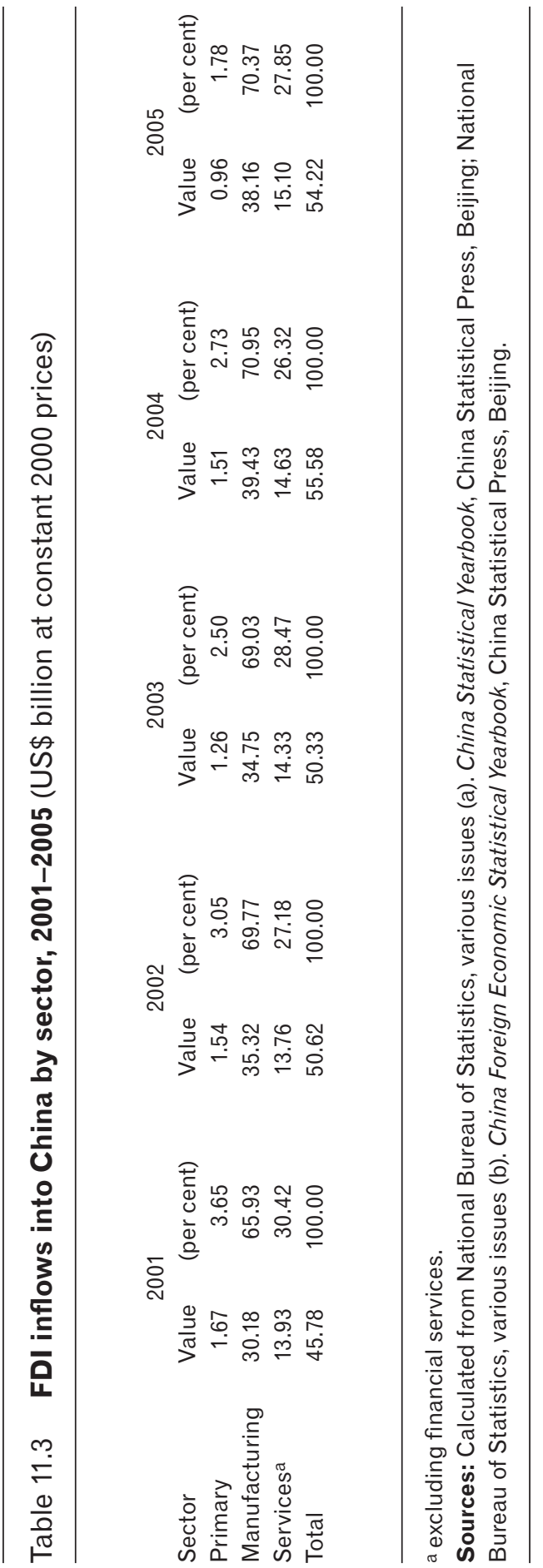


and the rapid loss of overall comparative advantage in agricultural production in China (Chen 2006). In addition, China's agricultural land tenure system and the traditional small-scale, family-based agricultural production pattern have greatly limited the inflows of agricultural FDI with large-scale production and advanced technology. Therefore, China will not attract large amounts of FDI inflows into its agricultural sector without fundamentally changing its land tenure system and dramatically reforming the traditional farming pattern.

It is expected that after accession, more FDI will flow into the services sector, however, such inflows have been increasing at a slow pace-from US $\$ 13.9$ billion in 2001 to US $\$ 15.1$ billion in 2005, with an annual growth rate of only 2 per cent. Because of the slow growth rate, the share of FDI inflows into the services sector declined from 30 per cent in 2001 to 28 per cent in 2005.

In the services sector, in 2005, FDI inflows concentrated mainly in the following industries: real estate (32 per cent); leasing and business services (22 per cent); transport, storage and postal services (11 per cent); electricity, gas and water production and supply (8 per cent); wholesale and retail trade (6 per cent); and information, computer services and software (6 per cent). Together, the above industries received 86 per cent of total FDI inflows into the services sector.

In 2005, China for the first time published the data for FDI inflows into its financial sector: they were US $\$ 12.1$ billion in 2005 and US $\$ 6.5$ billion in 2006. By the end of 2005, 72 foreign banks from 12 countries and regions had established 254 operational institutions; 117 foreign banks from 40 countries and regions had established 240 representative offices in China, and the total assets of foreign banks increased to US $\$ 87.7$ billion. There were 40 foreign-invested insurance companies, and their business accounted for 7 per cent of China's insurance market (Zhang 2006).

China made substantial commitments to the WTO to open its services sector to international trade and FDI. However, it has taken a step-by-step approach to implementing these commitments. In most of the services sectors-especially in telecommunications, banking and insurance, wholesale and retail, storage and transportation-China will fulfil its commitments in three to five years after accession.

China's services sector has been underdeveloped in the national economy. The share of the services sector in China's GDP has been about 30 per cent, while the global average is about 40 per cent. Obviously, the slow development of this sector will have a serious bottleneck effect on the overall development of China's economy. 
There are many reasons for the slow development of China's services sector-two of the most important are the closed nature of the sector and monopoly. Before China's WTO accession, its services sector was relatively closed to foreign direct participation, which effectively protected the state monopoly. At present, many of China's service industries are still monopolised by state-owned enterprises, especially in finance and telecommunications.

Opening the services sector has been one of the most important issues in the bilateral negotiations for China's WTO accession. China has made some important and concrete commitments in opening the sector to foreign investors and it is expected that with full implementation, it will attract more FDI inflows.

\section{Changes in FDI in the manufacturing sector}

FDI inflows into China have been directed overwhelmingly to the manufacturing sector, and foreign-invested firms have become a major part of this sector. In 2005 , foreign-invested firms made up 22 per cent of manufacturing enterprises, held 32 per cent of manufacturing assets, employed 32 per cent of the manufacturing labour force and contributed 33 per cent of manufacturing value-added.

Since China's accession to the WTO, foreign-invested firms in the manufacturing sector have undergone rapid expansion and structural changes.

Rapid expansion of foreign-invested firms in the manufacturing sector From 2001 to 2005, foreign-invested firms in the manufacturing sector expanded dramatically. The total assets of these firms grew from 1,386 billion yuan in 2001 to 2,952 billion yuan in 2005-an increase of 113 per cent. Compared with domestic firms - whose total assets increased by 50 per cent between 2001 and 2005 - the growth of foreign-invested firms was more than two times higher (Table 11.4).

Among the three industry groups, from 2001 to 2005, the growth in total assets of foreign-invested firms was the highest in technology-intensive industries ${ }^{5}$-increasing 137 per cent-followed closely by capital-intensive industries, ${ }^{6}$ which increased 125 per cent. Foreign-invested firms' total assets in labour-intensive industries ${ }^{7}$ increased by 81 per cent.

From 2001 to 2005, the expansion of foreign-invested firms was particularly significant in furniture manufacturing (183 per cent), chemical materials and products (128 per cent), ferrous metal smelting (297 per cent), non-ferrous metal smelting (193 per cent), general machinery (145 per cent), special machinery (206 per cent), transport equipment (134 per cent), electronics and 


\section{Table 11.4 Total assets of foreign-invested and domestic firms in the manufacturing sector, 2001 and 2005 (billion yuan in constant 1991 prices)}

\begin{tabular}{|c|c|c|c|}
\hline Industry & 2001 & 2005 & Change (per cent) \\
\hline \multicolumn{4}{|l|}{ Foreign-invested firms } \\
\hline Food processing & 40.3 & 85.3 & 112.0 \\
\hline Food manufacturing & 38.1 & 59.4 & 56.1 \\
\hline Beverage manufacturing & 42.7 & 54.5 & 27.5 \\
\hline Tobacco processing & 1.0 & 0.8 & -20.0 \\
\hline Textiles & 73.8 & 145.9 & 97.7 \\
\hline Clothing and other fibre products & 46.0 & 74.3 & 61.6 \\
\hline Leather and fur products & 29.2 & 57.2 & 96.3 \\
\hline Timber processing & 15.0 & 19.7 & 31.2 \\
\hline Furniture manufacturing & 10.5 & 29.7 & 182.7 \\
\hline Paper and paper products & 52.8 & 104.6 & 98.0 \\
\hline Printing & 21.3 & 28.6 & 34.1 \\
\hline Cultural, educational and sports goods & 18.6 & 32.4 & 74.2 \\
\hline Petroleum refining and coking & 22.4 & 38.0 & 69.6 \\
\hline Chemical materials and products & 85.3 & 194.3 & 127.9 \\
\hline Medical and pharmaceutical products & 31.9 & 59.4 & 86.5 \\
\hline Chemical fibres & 18.3 & 36.9 & 101.8 \\
\hline Rubber products & 24.1 & 44.4 & 83.9 \\
\hline Plastic products & 57.4 & 108.9 & 89.7 \\
\hline Non-metal mineral products & 71.0 & 112.0 & 57.8 \\
\hline Ferrous metal smelting & 27.8 & 110.3 & 297.3 \\
\hline Non-ferrous metal smelting & 16.9 & 49.7 & 193.4 \\
\hline Metal products & 61.3 & 89.3 & 45.5 \\
\hline General machinery & 56.8 & 139.4 & 145.5 \\
\hline Special machinery & 25.3 & 77.2 & 205.6 \\
\hline Transport equipment & 117.5 & 274.9 & 133.9 \\
\hline Electrical machinery and equipment & 96.7 & 191.8 & 98.4 \\
\hline Electronics and telecommunications equipment & 263.8 & 649.3 & 146.2 \\
\hline Instruments and meters & 20.6 & 55.4 & 169.3 \\
\hline \multicolumn{4}{|l|}{ By industry group } \\
\hline Labour intensive & 506.6 & 915.6 & 80.7 \\
\hline Capital intensive & 384.6 & 863.8 & 124.6 \\
\hline Technology intensive & 494.9 & $1,172.6$ & 136.9 \\
\hline Total & $1,386.2$ & $2,951.9$ & 113.0 \\
\hline \multicolumn{4}{|l|}{ Domestic firms } \\
\hline Labour intensive & $1,104.9$ & $1,713.7$ & 55.1 \\
\hline Capital intensive & $2,052.2$ & $2,997.7$ & 46.1 \\
\hline Technology intensive & 985.3 & $1,487.7$ & 51.0 \\
\hline Total & $4,142.3$ & $6,199.2$ & 49.7 \\
\hline
\end{tabular}

Source: National Bureau of Statistics, various issues (a). China Statistical Yearbook, China Statistical Press, Beijing. 
telecommunications equipment (146 per cent), and instruments and meters (169 per cent), which had an above-average rate of increase in total assets (Table 11.4). It is interesting to note that in the above nine industries, only one (furniture manufacturing) is a labour-intensive industry, while the others are capital and technology intensive.

The relative importance of foreign-invested firms in the manufacturing sector

Because of the high growth rate in investment, foreign-invested firms have become increasingly important in the manufacturing sector. In terms of total assets, the share of foreign-invested firms in the manufacturing sector increased from 25 per cent in 2001 to 32.3 per cent in 2005. In other words, one-third of the total assets of China's manufacturing sector were held by foreign-invested firms in 2005.

Among the three industry groups, foreign-invested firms in technologyintensive industries gained a greater share, and therefore, more importance than those in labour-intensive and capital-intensive industries in the manufacturing sector. By 2005 the share of foreign-invested firms in technology-intensive industries reached 44 per cent-increasing 11 percentage points over 2001 (Figure 11.4). The share in labour-intensive industries increased to 35 per cent in 2005_rising by 3 percentage points compared with 2001. The share in capitalintensive industries is still relatively low compared with those in technologyintensive and labour-intensive industries; however, it also increased-to 22 per cent in 2005, rising by 6.6 percentage points from 2001.

With such rapid growth, foreign-invested firms in some industries have already gained dominant or significant positions in the manufacturing sector. Foreign-invested firms have gained a dominant position in: leather and fur products (58.5 per cent); furniture manufacturing (57.5 per cent); cultural, educational and sports goods (63.7 per cent); and electronics and telecommunications equipment (71.9 per cent). The shares of foreign-invested firms have reached between 40 and 50 per cent of the industries' total assets in: clothing and other fibre products (46.6 per cent); paper and paper products (44.9 per cent); rubber products ( 45.4 per cent); plastic products ( 49.1 per cent); and instruments and meters (49.7 per cent).

The structure of foreign-invested firms in the manufacturing sector

Empirical studies have revealed that multinational enterprises, relative to indigenous firms, tend to concentrate their activities in sectors in which the 


\section{Figure 11.4 Share of foreign-invested firms in manufacturing, 2001 and 2005 (per cent)}

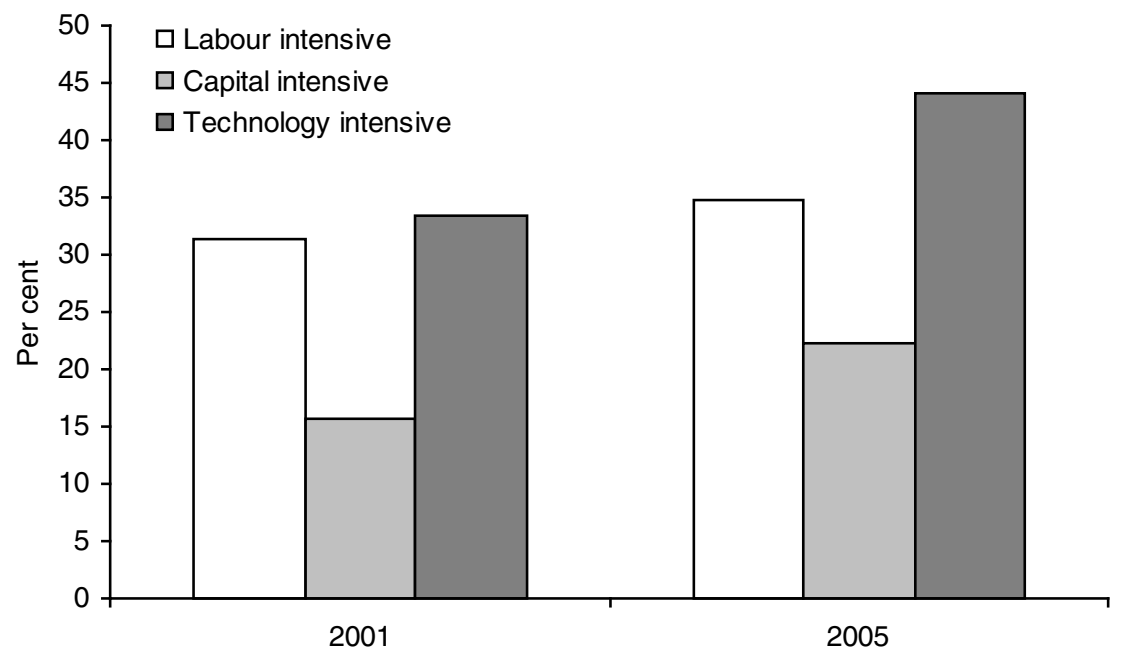

Source: National Bureau of Statistics, various issues (a). China Statistical Yearbook, China Statistical Press, Beijing.

revealed comparative advantage index is greater than one, or is increasing over time (Dunning 1993) - in other words, in the industries in which the country has a comparative advantage or the comparative advantage is increasing.

For developing economies, because they have a comparative advantage in labour-intensive activities, inward FDI flows usually concentrate in labourintensive industries. In the case of China, in the early stage of FDI inflows into the manufacturing sector, foreign-invested firms were concentrated overwhelmingly in labour-intensive industries. By the end of 1995, in terms of the total assets of foreign-invested firms in the manufacturing sector, 47 per cent were in labour-intensive industries, while only 25 per cent and 27 per cent were in capital-intensive and technology-intensive industries respectively.

With rapid economic growth, a high level of capital accumulation, improvements in human capital development and technology progress, China's comparative advantage has changed rapidly. Though it still has a strong comparative advantage in labour-intensive activities due to its huge population and abundant labour supply, China has greatly increased its comparative 
advantages in capital-intensive and technology-intensive activities. As a result, FDI flows into China's manufacturing sector have shifted gradually from a high concentration in labour-intensive industries towards increasing investment in capital-intensive and technology-intensive industries.

By the end of 2001, the structure of foreign-invested firms in the manufacturing sector had changed. In terms of the total assets of such firms, the share in labour-intensive industries had fallen to 36 per cent, while shares in capital-intensive and technology-intensive industries had risen to 28 per cent and 36 per cent respectively.

Since China's accession to the WTO, FDI in its manufacturing sector has made even further and larger structural changes. Although a large amount of FDI still flows into labour-intensive industries, the share of such industries in the total assets of foreign-invested firms has continued to fall, while shares of capital-intensive and technology-intensive industries in the total assets have been increasing. By the end of 2005, the investment structure of foreign-invested firms in China's manufacturing sector had changed fundamentally (Figure 11.5). Technology-intensive industries have surpassed labour-intensive industries and become the most important and the largest sector in receiving FDI. In terms of the total assets of foreign-invested firms, the share of technology-intensive industries has increased to 40 per cent, while the share of labour-intensive industries has fallen to 31.02 per cent. Capital-intensive industries have also increased their importance in receiving FDI: the share has increased to 29.26 per cent of the total assets of foreign-invested firms.

In 2005, electronics and telecommunications equipment industries attracted the largest amount of FDI, accounting for 22 per cent of the total assets of foreign-invested firms, followed by transport equipment ( 9 per cent); chemical materials and products ( 7 per cent); electrical machinery and equipment ( 7 per cent); and textiles ( 5 per cent). Together, the above five industries held nearly 50 per cent of the total assets of foreign-invested firms. It is worth noting that, except for the textiles industry, the other four industries are all capital and technology intensive.

The above analysis reveals three important characteristics of FDI inflows into the manufacturing sector since China's accession to the WTO. First, such inflows have increased significantly. The growth rate of investment in the total assets of foreign-invested firms was more than twice as high as that of domestic firms.

Second, although FDI inflows into all three industry groups in the manufacturing sector increased dramatically, the growth rates of FDI inflows into technology-intensive and capital-intensive industries were much higher 


\section{Figure 11.5 Structural changes of foreign-invested firms in manufacturing, 1995, 2001 and 2005 (per cent)}

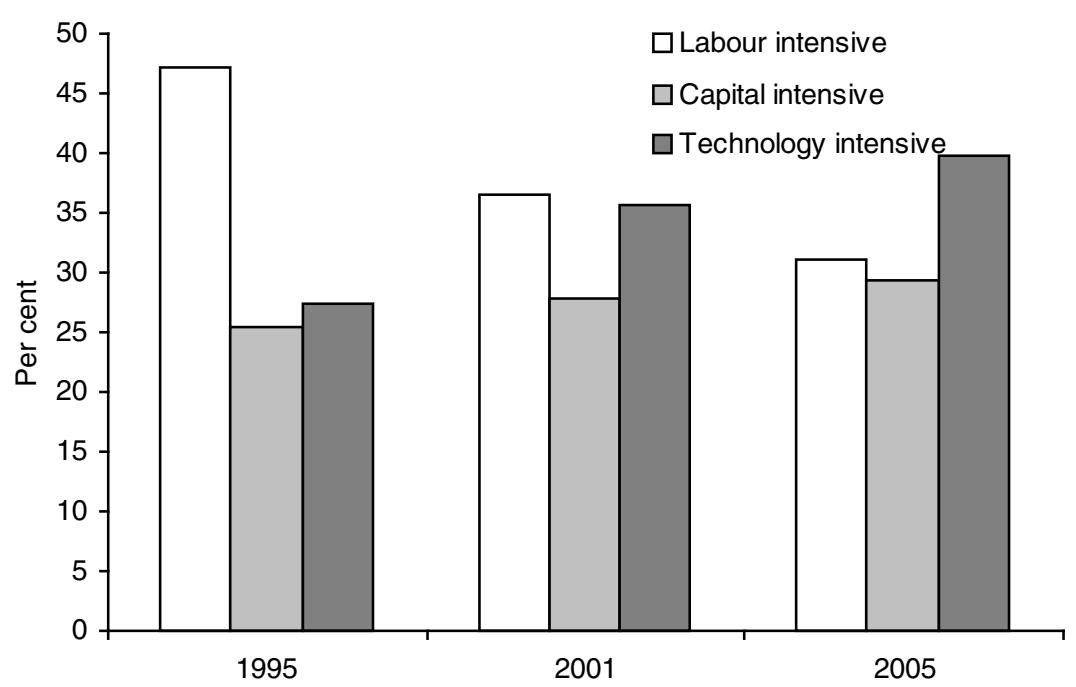

Source: National Bureau of Statistics, various issues (a). China Statistical Yearbook, China Statistical Press, Beijing.

than that into labour-intensive industries. As a result, the relative importance of foreign-invested firms in the three industry groups has changed: technologyintensive industries have surpassed labour-intensive industries. In 2005, foreign-invested firms in technology-intensive industries held 44 per cent of the total assets, while those in labour-intensive industries held 35 per cent of the total assets.

Third, FDI inflows into the manufacturing sector have gradually changed investment structures, shifting from a high concentration in labour-intensive industries towards increasing investment in technology-intensive and capitalintensive industries. As a result, the last two have become increasingly important to FDI, and, in 2005, their combined share reached 69 per cent of the total assets of foreign-invested firms in the manufacturing sector.

Several factors could be attributed to the changing structure of FDI in the manufacturing sector. First, China's changing pattern of comparative advantage in its economy has influenced the investment pattern. Although China still has a strong comparative advantage in labour-intensive activities, it has greatly 
increased its comparative advantages in capital-intensive and technologyintensive activities. As foreign-invested firms tend to invest in the industries in which the host country has a comparative advantage or in which the advantage is increasing, it is expected that China's increasing comparative advantage in capital-intensive and technology-intensive activities will attract increasing FDI inflows into these industries.

Second, through enterprise reform and intense competition, China's domestic firms have greatly improved their competitiveness. In 2005, the labour productivity of domestic firms in labour-intensive industries had surpassed that of foreigninvested firms in the manufacturing sector. ${ }^{8}$ The increasing, fierce competition from domestic firms in labour-intensive industries has seen foreign-invested firms gradually losing competitiveness in such industries, pushing FDI towards capital-intensive and technology-intensive industries, in which foreign-invested firms have relatively strong competitiveness compared with domestic firms. ${ }^{9}$

Third, China has greatly improved its business environment and strengthened intellectual property protection, which has increased the confidence of foreign investors, encouraging them to bring more capital and technology through their investments.

Fourth, increasing per capita income and the enlargement of China's domestic market demand for high-quality goods attract increasing numbers of capital-intensive and technology-intensive multinational enterprises to China.

\section{Conclusion}

Since China's accession to the WTO, with the implementation of its WTO commitments and broader and deeper liberalisation in trade and investment, FDI inflows into China have resumed an upward trend.

Developing and industrialised economies have increased their investments in China. The growth rate of FDI inflows from developing economies is, however, much faster than that from industrialised economies. As a result, FDI inflows into China are still dominated by developing economies and the composition of FDI sources has barely changed. The increasing share of FDI inflows into China from other countries is, however, a positive indication of the diversification of FDI sources.

It is expected that China will remain an important host country for investments from developing economies into the future. It is also expected that with further implementation of its commitments to trade and investment liberalisation-particularly in strengthening intellectual property rights protection and opening more economic sectors, especially the services sector, 
to FDI_China will become an increasingly important host country for FDI from industrialised economies, which will increase the total and the quality of FDI inflows.

Since China's accession to the WTO FDI inflows are still concentrated overwhelmingly in the eastern region. Although there is an increasing trend of FDI inflows into the central region, inflows into the western region declined. The poor performance of the western region in attracting FDI inflows is attributed mainly to its poor investment environment. Although the Chinese government has undertaken massive investment projects to improve the overall investment environment in the west, the full effects will take a long time to materialise.

It was expected that with WTO accession and the opening up of the services sector, more FDI would flow into this sector. However, inflows have been increasing at a very slow pace. China made substantial commitments to the WTO to open its services sector to international trade and FDI, and has taken a step-by-step approach to implementation. In most of the services sectors, China will fulfil its commitments in three to five years after WTO accession. Therefore, it is unrealistic to expect that there will be a large immediate increase in FDI inflows into China's services sector. With further and full implementation of its commitments to the WTO, however, China will attract more FDI inflows into the services sector.

After China's accession into the WTO, FDI inflows continued to concentrate in the manufacturing sector. China's manufacturing is very competitive in attracting FDI inflows. It maintained its position as the number one destination for manufacturing and assembly in 2005 (A.T. Kearney Inc. 2007), and this sector will continue to attract large FDI inflows.

With the rapid increase in FDI inflows into manufacturing, foreign-invested firms in the sector have undergone some structural changes. Two changes are most important. First, the growth rate of FDI inflows into technology-intensive and capital-intensive industries was much higher than that of FDI inflows into labour-intensive industries. As a result, the relative importance of foreigninvested firms in technology-intensive industries has surpassed their relative importance in labour-intensive industries in the manufacturing sector. Second, the investment pattern of foreign-invested firms in manufacturing has been changing gradually. FDI inflows into the manufacturing sector have shifted from concentrating in labour-intensive industries towards increasing investment in technology-intensive and capital-intensive industries. As a result, the last two have become increasingly important to FDI.

In 2007, China passed the new corporate income tax law, which will take effect on 1 January 2008. The new law unified the tax rates for foreign and 
domestic enterprises at 25 per cent. It will bring China's tax laws closer to international standards and is a fulfilment of commitments to the WTO for equal treatment for domestic and overseas investors. Although meeting the WTO commitments will raise rates of taxation on foreign enterprises, it is not generally expected to have a significant effect on FDI in China. Its most important effect will be to reduce substantially the incentives for round-tripping, improving the quantity and quality of FDI inflows into the country.

\section{Notes}

1 China revised its GDP growth rate for the period 1979-2004 in January 2006. The revised rates for 2002, 2003 and 2004 were 9.1 per cent, 10 per cent and 10.1 per cent, respectively, and the GDP growth rates in 2005 and 2006 were 9.9 per cent and 10.7 per cent respectively.

2 The data are FDI inflows into non-financial sectors only. In 2005, China for the first time published the data for FDI inflows into its financial sector: they were US $\$ 12.1$ billion in 2005 and US $\$ 6.5$ billion in 2006 .

3 According to this strategy, western areas include 12 provinces, municipalities and autonomous regions-Sichuan, Chongqing, Guizhou, Yunnan, Gansu, Shaanxi, Qinghai, Ningxia, Xinjiang, Tibet, Guangxi and Inner Mongolia-as well as two prefectures-Enshi of Hubei Province and Xiangxi of Hunan Province.

4 Data for real FDI inflows by sector are not available before 1997.

5 Technology-intensive industries include medical and pharmaceutical products; general machinery; special machinery; electrical machinery and equipment; electronics and telecommunications equipment; and instruments and meters.

6 Capital-intensive industries include beverage manufacturing; tobacco processing; paper and paper products; petroleum refining and coking; chemical materials and products; chemical fibres; ferrous metal smelting; non-ferrous metal smelting; and transport equipment.

7 Labour-intensive industries include food processing; food manufacturing; textiles; clothing and other fibre products; leather and fur products; timber processing; furniture manufacturing; printing; cultural, educational and sports goods; rubber products; plastic products; non-metal mineral products; and metal products.

8 The ratio of labour productivity of foreign-invested firms to domestic firms in labour-intensive industries in the manufacturing sector in 2005 was 0.93. Calculated from China Statistical Yearbook 2006 (National Bureau of Statistics, various issues [a]).

9 The ratio of labour productivity of foreign-invested firms to domestic firms in capital-intensive and technology-intensive industries in the manufacturing sector in 2005 was 1.58 and 1.43 respectively. Calculated from China Statistical Yearbook 2006 (National Bureau of Statistics, various issues [a]). 


\section{References}

A.T. Kearney Inc., 2007. 2005 Foreign Direct Investment Confidence Index. Available from www.atkearney.com

Breslin, S., 2003. Foreign direct investment in China: what the figures don't tell us, Paper presented at Asia-Link Conference, 'Regional governance: greater China in the 21st century', 24-25 October, University of Durham.

Chen, C., 2002. 'Foreign direct investment: prospects and policies', in China in the World Economy: the domestic policy challenges, Organisation for Economic Co-operation and Development, Paris:321-58.

_- 2006. 'Changing patterns in China's agricultural trade after WTO accession', in R. Garnaut and L. Song (eds), The Turning Point in China's Economic Development, Asia Pacific Press, The Australian National University, Canberra:227-55.

Dunning, J., 1993. Multinational Enterprises and the Global Economy, AddisonWesley, Wokingham.

Harrold, P. and Lall, R., 1993. China reform and development in 1992-93, World Bank Discussion Paper, No.215, World Bank, Washington, DC.

$\mathrm{He}, \mathrm{Q} ., 2006$. 'China's FDI policy is undergoing important changes' (in Chinese), My China News Digest, 12 November.

Hu, F., 1999. Global economics, Paper No. 14, 26 April, Goldman Sachs, New York.

McKibbin, W. and Wilcoxen, P., 1998. The global impacts of trade and financial reform in China, Working Paper 98-3, Asia Pacific School of Economics and Management, The Australian National University, Canberra.

Morisset, J., 2003. Tax incentives: using tax incentives to attract foreign direct investment, Note No. 253, Public Policy for the Private Sector, World Bank Group, Private Sector and Infrastructure Network. Available from http://rru. worldbank.org/Viewpoint/index.asp

National Bureau of Statistics (NBS), various issues (a). China Statistical Yearbook, China Statistical Press, Beijing.

- - various issues (b). China Foreign Economic Statistical Yearbook, China Statistical Press, Beijing.

Office of the West Development Leading Group of the State Council, 2000. Guojia Zhichi Xibu Dakaifa de Youguan Zhengce Cuoshi (State's Relevant Policies and Measures on Supporting the Development of West Areas).

United Nations Conference on Trade and Development (UNCTAD), 2000. World Investment Report: cross-border mergers and acquisitions and development, United Nations, New York and Geneva.

_—, 2007. Rising FDI into China: the facts behind the numbers, United Nations 
Conference on Trade and Development Investment Brief No. 2, Investment Issues Analysis Branch, New York and Geneva. Available from http://www. unctad.org/

Walmsley, T. and Hertel, T., 2000. China's Accession to the WTO: timing is everything, Centre for Global Trade Analysis, Purdue University.

Wu, F., Siaw, P.T., Sia, Y.H. and Keong, P.K., 2002. 'Foreign direct investments to China and Southeast Asia: has ASEAN been losing out?', Economic Survey of Singapore, Third Quarter:102.

Xinhua News Agency, 2007. 'Parliament adopts corporate income tax', 16 March.

Xinwen Shishi, 2007. 'China's corporate income tax will be unified to 25\%' (in Chinese), 8 March.

Zhang, Y., 2006. China's economic progress and its role in strengthening cooperation between East and South Asia, Paper prepared for the Asian Development Bank Research Project on Strengthening East and South Asia Economic Relations, Asia Development Bank, Manila. 